\title{
Food Security and Ecological Degradation: Challenges and Opportunities for Inclusive Growth
}

\author{
Mamta Chhabra Sharma ${ }^{1^{*}}$ and Sandeep Kumar Sharma \\ ${ }^{1}$ Department of Chemistry, Kirori Mal College, University of Delhi, Delhi-110007, India \\ 2 Rajdhani College, University of Delhi, New Delhi-110015, India \\ *Corresponding author: Mamta Chhabra Sharma, Department of Chemistry, Kirori Mal College, University of Delhi, India, Tel: +91-9350547156; E-mail: \\ mamta610@gmail.com
}

Received date: July 03, 2014; Accepted date: November 11, 2014; Published date: November 22, 2014

Copyright: @ 2014 Mamta S, et al. This is an open-access article distributed under the terms of the Creative Commons Attribution License, which permits unrestricted use, distribution, and reproduction in any medium, provided the original author and source are credited.

\begin{abstract}
Food security is primarily associated to socioeconomic as well as environmental conditions of an ecosystem. The improvement in the agricultural sector and the upgrading of the food security situation are seen as vital constituents to sustainable development. However, continuing population growth, impacts of climate change and ecological degradation add to an unprecedented blend of pressures that threaten existing struggles and solutions. Strategies should be evolved so as to reduce the food gap by comprehensive food production on existing agricultural space and need not necessarily produce more food as a trade of ecological degradation. The environmental impact of food production should be reduced, particularly greenhouse gas emissions and stress on water and natural ecosystems. This article discusses the challenges and opportunities of inclusive growth in a sustainable way.
\end{abstract}

\section{Introduction}

Food is the most essential resource, next only to oxygen and potable water. Food insecurity and undernourishment are widespread in India. Here the employments and well-being of poor population is critically reliant on agriculture and the ecosystem services from the local backdrop that support their livelihoods and income. $98 \%$ of food insecure people live in developing countries like India. While India has witnessed impressive economic growth in recent years, yet she scuffles with widespread poverty and hunger. India's poor population amounts to more than 300 million people and one cannot ignore a very disturbing fact that largest number of hungry people in the world estimated to be 214 million people reside here. Projections have shown that $46 \%$ of children below three years are underweight, $79 \%$ of children aged 6-35 months are anemic, $23 \%$ have a low birth weight and infant mortality rate is 68 out of 1000 . Due to scarcity of food $33 \%$ of women and $28 \%$ of men have a Body Mass Index (BMI) below normal.

Food system includes crops, fish and livestock. Hence food security is the dependent on management of factors such as water, land, aquatic resources, crops and domestic animals. India is a space of geographical diversity, stretching from the mountains of the Great Himalaya in north to the sea coasts of Kanya kumari in south and from the Thar deserts of Rajasthan and Gujarat in west to the humid forests of the north-east. There is a diverse and interesting range of climates, soil types and water availability in the entire space. The situation is very challenging as each geographical location has its own requirement. Thus there is an urgent need of suitable policies to stimulate the ability of people to produce and purchase food, and the ability of their families to derive maximum nutrition from it. FAO High Level Experts panel on Food Security [1] opined, "agriculture in the 21 st century faces multiple challenges: it has to produce more food and fiber to feed a population expected to grow by over a third (or 2.3 billion people) between 2009 and 2050, more feedstock for a potentially huge bioenergy market, contribute to overall development in the many agriculture-dependent developing countries, adopt more sustainable production methods and adapt to climate change".

Apart from other factors, one cannot ignore unusually higher percent of food grains is being wasted at different stages of food supply chains which includes the actual handling, storage, transport of food grains and vegetables before they even reach the consumer's platter.

\section{Food security}

According to the United Nations Food and Agriculture Organization [1], "food security exists when all people, at all times, have physical and economic access to sufficient, safe and nutritious food to meet their dietary needs and food preferences for an active and healthy life." This definition encompasses the multi-dimensional aspect of food security. Committee on World Food Security identified four main dimensions or "pillars". Availability is ensured if adequate amounts of food are produced and are ready to have at people's disposal. Availability of food is a necessary condition for food security. India is self-sufficient in cereals since twenty years after independence; however is deficit in pulses and oilseeds (Figure 1).

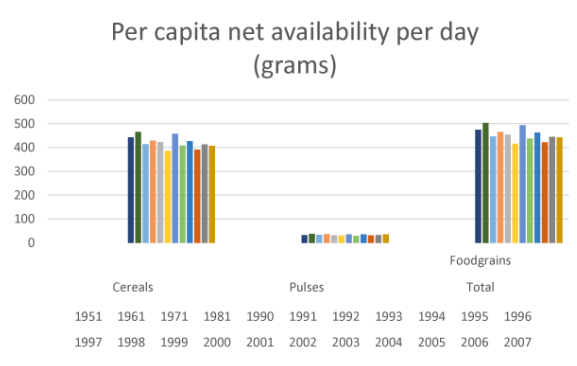

Figure 1: Net Availability of Food grains (Source: Economic Survey 2008-2009, Government of India). 
Access is ensured when all households and all individuals within those households have sufficient resources to obtain appropriate foods (through production, purchase, or donation) for a nutritious diet. Immediate means to food security is subsistence farming where women play a major role. In this sector role of women is paramount but on the contrary access to credit ownership of land is the least. Agricultural investments keeping specifically women in mind should be encouraged to overcome this lack of access (Figure 2).

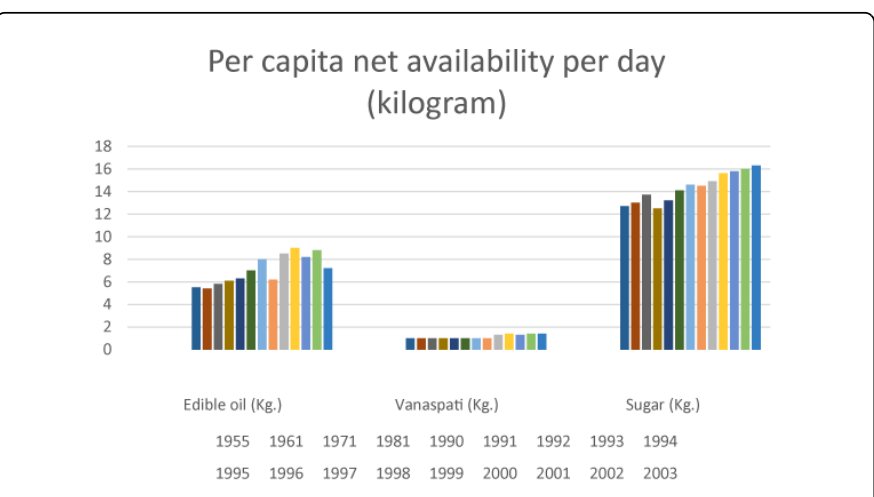

Figure 2: Net Availability of Food grains in kilograms.

Group efforts such as women's cooperatives, producer women's groups etc. should be encouraged to overcome restrictions of small and uneconomic land holdings, for the propagation of agricultural technology and other inputs in addition to marketing of produce $[2,3]$. NGO like Deccan Development Society (DDS), enables women from landless families to access various government schemes to establish claims on land, through purchase and lease. DDS ensured local food security in an experimentation in Andhra Pradesh where the women's collectives called 'sangams' improved 6,000 acres of degraded land, dalit women took cultivable land on lease, they organised their own public distribution of grains with accent on coarse cereals consumed by 65 per cent of our rural population and finally built grain banks at village level, and made systematic collection and preservation of seed varieties" [4]. Utilization is ensured when the human body is able to ingest and metabolize food. Nutritious and safe diets, an adequate biological and social environment, and a proper health care to avoid diseases help achieve adequate utilization of food. Strategies must not merely be focused at guaranteeing food security for all, but must also target at achieving the intake of safe, adequate and good quality foods that together make up a healthy and balanced diet. This would have its consequences for all constituents of the food chain. It is interesting to study consumption patterns worldwide and deliberate on the prospective of the food and agriculture sector to meet the demands and challenges posed by this scenario. Stability is ensured when the three other pillars are maintained over time.

\section{Challenges and Opportunities}

\section{Ecological degradation}

Main contributor of GHG Emission: GHG emissions including methane and nitrous oxide result primarily from sources like ruminant livestock, which generate methane in their stomachs and both methane and nitrous oxide from litters they deposit on grasslands. This is in addition to manure managed in storage facilities and barns, primarily from pigs, dairy, and some beef feedlots. Paddy crops like rice release both methane and nitrous oxide. Croplands and pastures release nitrous oxide from the interactions of soil bacteria with nitrogen, originating from fertilizer, manure, or from the fixation of nitrogen by leguminous crops. Methane and nitrous oxide are released from burning crop residues.

Ruminant like cows, sheep, and goats break down fibrous feeds, but that results in high quantities of methane and waste and even then does not provide enough nourishment for animals to produce milk and meat at high levels. Strategies should be evolved to provide more digestible feeds with higher protein content to improve the output of ruminants and lessen the quantity of methane and nitrous oxide, they generate for each ton of feed. This would lead to higher quality and quantity of meat or milk per ton of greenhouse gas emissions. Nitrogen fertilizer applied directly in smaller amounts neither runs off the field nor converts into nitrous oxide, a global warming gas. But bacteria and other microorganisms turn nitrogen into forms like ammonia, which goes into the air, and nitrate, that leaches. The formation of nitrate, and its subsequent breakdown into nitrogen gas by other organisms, leads to formation of nitrous oxide.

Largest consumer of Fresh water resources: Scarcity of water is a major factor that limits the food security. Globally 70 percent of all freshwater withdrawn from rivers, lakes, and aquifers is utilized for agriculture [5], and 80-90 percent of such water is actually consumed and not returned. Age old water saving technologies and practices such as drip irrigation, should be adopted, along with improvements in irrigation methods such as arranging irrigation according to plant needs, and replacing soil with concrete linings for irrigation canals.

Largest cause of conversion of natural ecosystems: Expanding agricultural land is the primary cause of natural ecosystem and loss of flora and fauna. At the local level, there is reduction in the biodiversity and natural habitats are adversely affected by conversion of natural ecosystem. Irrigation, pesticides, insecticides, eutrophication add to the whole scenario adversely. Unsustainable agricultural activities result in soil erosion, nutrient mining etc.

Climate change and population increase: Fast rate of population growth results in increased stresses on natural resources such as land, forests and water. In addition to increased population, there are certain factors like weather variability (viz., erratic rainfall, floods, droughts, thunderstorms, dry spells, cold spells, strong winds, landslides, hailstorms, mudslides and heat waves etc.), sudden rise in food prices, epidemics cannot be ignored. Directly or indirectly the climate change ultimately relates to increased human activity which changes the global atmosphere [6]. All these factors reinforce resulting in poor and under privileged become more food insecure.

Food loss and waste along the food value chain: "Loss and waste" refers to the eatable parts of plants and animals produced for human consumption but not eventually consumed by people. "Loss" refers to food that spills, spoils, incurs an abnormal reduction in quality such as bruising or wilting, or otherwise gets lost before it reaches the consumer [7] "Waste" refers to food that is of good quality and fit for consumption, but is not consumed because it is discarded after it reaches consumers-either before or after it spoils. Food loss and waste occurs along the entire food value chain and represents waste of labor, investment, water, land, material, and energy-and unnecessary greenhouse gas emissions. Food value chain comprises of Production; handling and storage; processing and packaging; distribution and marketing; and ultimately consumption. FAO [8] estimates have shown that roughly 32 percent of all food produced in the world in 
2009 was lost or wasted. In developing countries like India, major losses as high as three quarters occur at the production and storage stage. In India an huge amount of food is lost by rotting during inadequate storage as well as due to rodents. India has limited amounts of resources and food production requires major chunk of land, water, electricity and labour. With exponential increase in population, demand of food is increasing day by day. Strategies such as involvement of Private sector for world class storage to reduce food loss and waste would yield food supplies and provide significant economic and environmental benefits.

\section{Ecological sustainability and inclusive growth}

In the green and ecological context, sustainability reassures production and development approaches that preserve and protect our natural assets and lessen human impact on the environment. This includes protecting the present, past and future for e.g., present environmental resources (both in the natural and 'man-made' world), the safeguarding of historical sites and the expansion of environmental resources and assets for forthcoming consumption. To realize this objective, innovative ways should be initiated to reduce consumption and replenishment of resources consumed. Mitigation strategies should be employed to check ecological degradation which includes, practicing water harvesting, regulating ground water usage, replacing open water irrigation channels with closed pipelines, nitrogen fixing trees, encouraging water efficient irrigation technology, pest resistant and drought tolerant crops etc.. Emergency food storage facilities should be constructed and maintained. Biodiversity and ecosystems must be protected by reducing greenhouse gas emissions, carbon footprints, air and water stress, and soil pollution. In the perspective of land use and food production, ecological sustainability demands that undeveloped land and employ food production methods that will have a minimal impact on earth must be conserved. [9], Bootsma and Brown [10], Das [11,12], Dickerson [13], Doering [14], Gomez [15], James, et al. [16], King County [17], Pretty [18], Protz [19], Sivakumar [20,21], Wilhite [22], Wright [23], Krejci and Beamon BM [24].

One way is to employ an integrated crop and livestock system that manages crops and animals on the same smallholding in a way that they will complement each other. This usually comprise a herd of ruminants (animals like sheep, goats or cattle), which graze a pasture to build up the soil. Over the time enough soil organic matter builds up to the point where crops can be supported. This system increases the assortment, along with environmental sustainability, of both sectors. At the same time it provides prospects for accumulative overall production of farming. Shifting to a greener society to achieve a sustainable society requires serious changes in policy matters which can be implemented at the local and as well as higher levels. Agriculture sector has to progress for inclusive growth of the society and this includes low carbon agriculture and efficient water management of food production.

Shift to sustainable agriculture should not be seen as a compromise on food security. Apart from wheat, rice, oilseeds, certain pulses etc. often regarded main food crops, the food basket can be increased by including millets, coarse cereals, dry land fruits, uncultivated greens etc. as they also bring in nutrition security.

Illiterate women and men suffer due to lack of access to information such as technical advice that could help them adapt to climate change. Formal, informal and non-formal educational systems need to warrant that citizens receive the necessary talents and training in how to express concerns, collect, handle and relate appropriate information, thereby plan a course of action, make responsible choices, analyze and assess the magnitudes of their actions, and deliberate upon the consequence they have made locally, nationally and in a global context. India is a young nation, so it becomes more significant for the youth.

Climate information can be used for reduction of economic and environmental risks and reinforcing resilience against climate variability's [25]. The switch from information to knowledge involves the integration of locally relevant know-hows and practices into climatic information and scientific evidence. In a way it comes from scientific research as well as experience, customs and traditions [26]. Appropriate understanding can only be generated when information is contextualized in local perspective and is delivered in forms acceptable to the end users. Access of climate change knowledge to the rural population is still a huge challenge. Scientific knowledge on the subject should to be translated into a language that all concerned persons including the decision-makers and communities apprehend.

\section{Conclusion}

Strategies should be evolved so as to reduce the food gap by comprehensive food production on existing agricultural space and need not necessarily produce more food as a trade of ecological degradation. The environmental impact of food production should be reduced, particularly greenhouse gas emissions and stress on water and natural ecosystems. In addition to this food consumption should be reduced in ways that safeguard human well-being. By 2050, world population will be around 9.1 billion and the cumulative impacts of climate change, sustainable use of water and ecosystems for food security pose a great challenge. Increased investment in small scale, more sustainable, agro ecological techniques can replace current norm of agricultural venture which displaces millions of people around the world for massive single production. There is a common struggle for a more sustainable and equitable food system with such a diverse array of people around the world. This is both optimistic and stimulating.

\section{References}

1. FAO (2009) The state of Food and Agriculture, Rome, Italy: Food and Agriculture Organisation of the United Nations.

2. Aggarwal PK (2009) Vulnerability of Indian Agriculture to Climate Change: Current State of Knowledge, Indian Agricultural Research Institute, New Delhi.

3. Aggarwal PK, Baethegen WE, Cooper P, Gommes R, Lee B, Meinke H, Rathore LS, Sivakumar MVK (2010) Managing climatic risks to combat land degradation and enhance food security: key information needs, Proc Environ Sci, 1:305-312.

4. Krishnaraj M (2006) Is gender easy to study? Some reflections, Economic and Political Weekly 41 (42):4440-4443.

5. Foley JA, Ramankutty N, Brauman KA, Cassidy ES, Gerber JS, Johnston M, Mueller ND, O'Connell C, Ray DK, West PC, Balzer C, Bennett EM, Carpenter SR, Hill J, Monfreda C, Polasky S, Rockstrom J, Sheehan J, Siebert S, Tilman D, Zaks DPM (2011) Solutions for a cultivated planet, Nature 478: 337-342.

6. Pachauri RK, Reisinger A (Eds.) (2007) Climate Change 2007: Synthesis Report.

7. Alexandratos N, Bruinsma J (2012) World agriculture towards 2030/2050: The 2012 revision. Rome: Food and Agriculture Organization of the United Nations (FAO).

8. FAO (2011) The state of Food and Agriculture, Rome, Italy: Food and Agriculture Organisation of the United Nations.

9. Agriculture and Agri-Food Canada (2007), Managing wet soils. 
Citation: Sharma MC, Sharma KS (2014) Food Security and Ecological Degradation: Challenges and Opportunities for Inclusive Growth. Int J Econ and Manage Sci 3: 200. doi:10.4172/2162-6359.1000200

Page 4 of 4

10. Bootsma A, Brown DM (2009) Freeze protection methods for crops, Ontario Ministry of Agriculture: Food and Rural Affairs.

11. Das HP (2005a) Agro meteorological impact assessment of natural disasters and extreme events and agricultural strategies adopted in areas with high weather risks, In: Natural Disasters and Extreme Events in Agriculture: Impacts and Mitigation, eds. M.V.K. Sivakumar, R.P. Motha and H.P. Das, Springer, Berlin, pp. 93-118.

12. Das HP (2005b) Agricultural drought mitigation and management of sustainable agricultural development in India, In: Natural Disasters and Extreme Events in Agriculture: Impacts and Mitigation, eds. M.V.K. Sivakumar, R.P. Motha and H.P. Das, Springer, Berlin, pp. 277-304

13. Dickerson GW (2004) "Row cover vegetable production techniques," New Mexico State University Cooperative Extension Service.

14. Doering OC (1998), "Making sense of climate change impacts," proceedings from the Upper Great Lakes Regional Assessment Workshop.

15. Gomez B (2005) Degradation of vegetation and agricultural productivity due to natural disasters, In: Natural Disasters and Extreme Events in Agriculture: Impacts and Mitigation, eds. M.V.K. Sivakumar, R.P. Motha and H.P. Das, Springer, Berlin, pp. 259-276.

16. James TA, Croissant RL, Peterson G (2009) Controlling soil erosion from wind, Colorado State University Extension.

17. King County Department of Natural Resources and Parks: Water and Land Resources Division (2008), Snoqualmie Flood-Farm Task Force Report.

18. Pretty J (2001) The rapid emergence of genetic modification in world agriculture: contested risks and benefits, Environmental Conservation, 28:248-262.
19. Protz M (1999) Communicating hurricane preparedness for agriculture, forestry and fisheries in the Caribbean.

20. Sivakumar MVK (2005a) Impacts of natural disasters in agriculture, rangeland and forestry: an overview, In: Natural Disasters and Extreme Events in Agriculture: Impacts and Mitigation, eds. M.V.K. Sivakumar, R.P. Motha and H.P. Das, Springer, Berlin.

21. Sivakumar MVK (2005b) Impacts of sand storms/dust storms on agriculture, In: Natural Disasters and Extreme Events in Agriculture: Impacts and Mitigation, eds. M.V.K. Sivakumar, R.P. Motha and H.P. Das, Springer, Berlin, pp. 159-178.

22. Wilhite DA (2005) The role of disaster preparedness in national planning with specific reference to droughts, In: Natural Disasters and Extreme Events in Agriculture: Impacts and Mitigation, eds. M.V.K. Sivakumar, R.P. Motha and H.P. Das, Springer, Berlin, pp. 23-38.

23. Wright WJ (2005) Agricultural drought policy and practices in Australia, In: Natural Disasters and Extreme Events in Agriculture: Impacts and Mitigation, eds. M.V.K. Sivakumar, R.P. Motha and H.P. Das, Springer, Berlin, pp. 195-218.

24. Krejci CC, Beamon BM (2010) Environmentally-conscious supply chain design in support of food security, Operations \& Supply Chain Management: An International Journal, 3:14-29.

25. Glantz MH (ed) (2005) Usable science 9: El Niño early warn- ing for sustainable development in Pacific Rim countries and islands. Report of workshop held 13-16 September 2004. ISSE/NCAR, Boulder, CO

26. Lebel L (2011) Policy Research Brief No 2 Adaptation Knowledge Regional Climate Change Adaptation Knowledge Platform for Asia. 